\title{
ON LIBERATION AND LIBERTY: MARCUSE'S AND MILL'S ESSAYS COMPARED
}

\section{Clarence Morris $\dagger$}

The parts of this essay are three. The first abridges Marcuse's essay on our coming liberation as the result of an impending revolution; the second sums up Mill's essay on the desirability of extensive individual liberty; the third compares and discusses the first two.

\section{$I *$}

In An Essay on Liberation, ${ }^{1}$ published in 1969, Marcuse charges that the elders of our society (especially the Establishment) are presently suppressing or thwarting all suggestions for radical change. Until, therefore, rebellious young whites and militant ghetto blacks can mount a revolution unseating the Establishment, our society will remain in thralldom to corporate capitalism. A quest for a zestful life, lived without hurting others, is a hopeless search in our society as it is now structured; men who accept the currently taught aspirations and seek to enjoy generally desired satisfactions injure themselves; corporate capitalism's dependents, by their fealty, perpetuate their own servitude. Thus most young rebels today refuse to school themseives to take conventional places in our obscene society. They hold the following objections :

(1) Society forces many people into jobs that keep them at stupid, inhuman, and unnecessary work.

(2) Society's booming business is often done on the backs of ghetto dwellers or by exploiting domestic or foreign colonials.

(3) Society is infested with violence, but expects the injured to suffer their hurts without murmuring.

(4) Society maintains its structure (including its allotments of power) by practicing waste, wreaking destruction, and distending human needs and desired satisfactions.?

† Professor of Law, University of Pennsylvania. J.D. 1925, University of Colorado; IL.M. 1926, Columbia University. Member, Pennsylvania, Texas, and Wyoming Bars.

* The following ideas are Marcuse's and not mine. I have reordered them. presented them out of context, and condensed them, often paraphrasing, rather than quoting, for clarity. When Marcuse's exact words are used, they are in quotation marks.

1 H. Marcuse, AN Essay on Itberation (1969).

2 Id. 62. 
The mass media are under the thumb of corporate capitalism and have stifled the case for radical change. Telecasting, broadcasting, and the press have dulled most people's emotions and have addicted their audiences to compulsive buying of mediocre wares. The media have convinced the masses that they should defer to capitalism's domination and defend the system that enslaves them. ${ }^{3}$

Every society has a second nature; this second nature consists of the hopes and responses that have been (and continue to be) introjected into the people's biology. A society's morality, therefore, is a system of organic norms of behavior. Once people are so conditioned, their acts are controlled by these introjections into their physical beings; they are receptive to and react to only certain stimuli, ignoring or repelling other excitants (which might affect differently conditioned people). In our consumer-oriented economy, men are libidinally and aggressively driven to acquire commodities; they resent any threat to reduce their access to the merchandise market. Until revolt reshapes the second nature of our society, significant improvement in social conditions is unlikely. ${ }^{4}$

Once the revolution dethrones corporate capitalism, the new society's goal will extend far beyond a collectivistic eradication of poverty. The revolution will aim at qualitative social change. The old ways of producing commodities will be scrapped and replaced by a system of production designed to meet freshly perceived, genuine, human needs. Reconstituted society will be characterized by solidarity, and, as a result, social goals will be harmonized with individual desires. An understanding respect for every individual's hopes will, perforce, eliminate exploitation. ${ }^{5}$ The guarantee that the revolution is genuinely humane will be attested by the appearance of two qualities in the new second nature of the citizenry: a percipient tenderness, and an instinctive recognition of and revulsion from falsehoods and evils. ${ }^{6}$ The new culture will be rooted in sensuousness and will create for itself an aesthetic environment. Parks and gardens will replace highways and parking lots, and areas of withdrawal will be sanctuaries from massive fun and tawdry relaxation. ${ }^{?}$

The development of more and better accoutrements of life will decelerate or stop; society will settle down to enjoy its hard-won technical and scientific progress, and will become satisfied with a reduced supply of equipment and wares. High-pressure selling will
3 Id. 15.
4 Id. 11.
5 Id. $87-88$.
6 Id. 88.
7 Id. 88-90. 
disappear. De-emphasis of the market will, unfortunately, retard the development of machines that relieve men from dull, timeserving tasks, but this minor setback is the price that must be paid for liberation from the despotic rule of merchandisers. ${ }^{8}$

When men are liberated, their newly won biological sensitivity will enable them to convert the techniques of production into arts; the differences between the quality of scientific thought and poetry will then vanish; all intellectual activities will merge into an overriding aesthetic ethos. ${ }^{9}$ Society itself will become a sensuous work of art, and its liberated members will evolve an environment in which making a living will no longer have ugly or aggressive aspects. ${ }^{10}$ Liberated men's incentives for work will be instinctual, because the human animal has a desire to unify and enhance his life, and his liberation releases libidinal energy for work when he lives in genuine freedom. "The social expression of the liberated work instinct is cooperation, which, grounded in solidarity, directs the organization of the realm of necessity and the development of the realm of freedom." 11

Marcuse holds out no hope that revolution can be averted by parliamentary procedures. Corporate capitalism has indoctrinated most of us so thoroughly that reforms made legally can be only piffling gestures-never significant advances toward a truly free society. ${ }^{12}$ The contaminated masses cling like barnacles to the market economy. " $[\mathrm{I}] \mathrm{t}$ makes sense to say that the [contemporary] general will is always wrong . . . ."13 [Shades of Rousseau's remonstrating ghost!]

The radicals of today are not yet able to launch a revolution. A profound and unmanageable economic crisis will, however, inevitably disrupt the capitalistic system. Then society's moral fiber will weaken. The symptoms of general demoralization will be a spread of discontent, an increase of mental illness and growth of unwillingness to work, indifference, inefficiency, and negligence. At that point in time the new forms of organizations that are needed to wage the struggle for liberation will emerge. ${ }^{14}$ The rebels are not yet very well organized; they are not yet in rapport with labor, the middle classes, or the masses. At the right time, nevertheless, they will radicalize the industrial working class ${ }^{15}$ and become the catalysts of revolution. ${ }^{16}$

\footnotetext{
8 Id. 90-91.

9 Id. 23-24.

10 Id. $45-46$.

11 Id. 91.

12 Id. 63.

13 Id. 65.

14 Id. 82-84.

15 Id. 54.

16 Id. 51-52.
} 
Nowadays many workers are much more highly educated than the laborers who formerly bore the brunt of exploitation. Contemporary workers are, one by one, becoming members of a scientific intelligentsia, competent to operate automated production machinery. As technology develops, industry needs more and more employees who have college educations. Current campus protests and confrontations, therefore, are especially provoking to the captains of corporate capitalism, whose reactions are, naturally, violent vituperation. ${ }^{17}$ The students, however, are not yet a vanguard; there is, for the time being, no main body of rebels behind them and willing to follow their lead. The student movement is nevertheless "the ferment of hope. . . . [I]t testifies to the alternative-the real need [for] and the real possibility of a free society." 18

Thus spoke Marcuse.

\section{II *}

Mill's influential, classic essay, On Liberty, which was first published in $1859,{ }^{19}$ starts with a discussion of the great powers wielded by bygone monarchs. Tolerance of their might was based on the belief that strong government is needed to repel foreign aggressors and suppress domestic disorders. Rulers with so much legitimate power were likely, however, to take advantage of their position and become tyrants. Earlier publicists, therefore, were likely to direct their concern with liberty to the prevention of the tyranny of monarchs. ${ }^{20}$ A time came when more democratic governments were in the offing and populaces came to believe that public officials would soon hold their places only so long as the public was satisfied with their services. An accepted corollary of this view was that officials whose powers were so limited would not have the opportunity to enthrall the public. ${ }^{21}$ The notion that government when it can readily be ousted is unlikely to become tyrannical was a misbelief, founded on pre-democratic imaginings. After popular government became a reality, such phrases as "self-government" and "the power of the people over themselves" lost some of their allure. The people who came to exercise power were not always the same as

17 Id. 59.

18 Id. 60.

* As in the preceding section of this essay, I have resorted to paraphrase. When Mill's exact words are used, they appear in quotation marks. The ideas that follow are, however, Mill's and not mine. All citations are to the edition published by E. P. Dutton in 1951, Everyman's Library (\#482 A).

19 J. S. Mill, ON LiberTy (1859).

$20 I d .86$.

21 Id. 87-88. 
those over whom it is exercised; self-government turned out to be the government of each by all the rest. "The will of the people, moreover, practically means the will of the most numerous . . . part of the people . . . '[T] the tyranny of the majority' is now generally included among the evils against which society requires to be on its guard." 22

Society has sanctions other than law for tyrannizing over dissidents. "Society can and does execute its own mandates: . . . it practices a social tyranny more formidable than many kinds of political oppression, since . . . it leaves fewer means of escape, penetrating much more deeply into the details of life, and enslaving the soul itself." 23

Mill does not argue for unlimited permissiveness. Legal and moral coercion aimed at the control of deviance is properly exercised over a member of civilized society when it is used to prevent him from harming others. Obnoxious conduct is permissible, but only when it does not infringe on "the interests of . . . another; or rather certain interests, which, either by express legal provision, or by tacit understanding, ought to be considered as rights . . . ." 24

Since speech rarely violates the rights of others, the privilege of free speech is accordingly broad, and is not lost even though the speaker is unmannerly and argues heatedly. Speech creating a clear and present danger of riot, however, exceeds this privilege. An assertion "that corn-dealers are starvers of the poor . . . ought to be unmolested when simply circulated through the press, but may justly incur punishment when delivered orally to an excited mob assembled before the house of a corn-dealer . . . ." 25

Utterance of half-truths advances the public interest. Enlightenment expands when new verity, embedded in error, is sifted out and burnished by being considered and discussed. ${ }^{26}$ Even the utterance of arrant mistakes can be socially valuable; men confronted with falsity develop a "clearer perception and livelier impression of truth, produced by its collision with error." 27

Informal social forces suppressing unpopular views are more deplorable than legal penalties exacted for dissidence. When the public stifles opinions held by men with inquiring minds, fearless thinkers with logical intellects are muted and the influence of conformers is en- 
hanced. $^{28}$ Freedom of discussion is not limited, however, to its power to advance the development of masterminds; the part discussion plays in the mental maturation of ordinary men is of even greater value. ${ }^{29}$

Experiments in new and different ways of living should be prized. " $[F]$ ree scope should be given to varieties of character, short of injury to others; and . . . the worth of different modes of life should be proved practically, when any one thinks fit to try them." 30 We not only should tolerate the piquancy of attractive loners, but we also should enact no laws forbidding vices and foibles like gambling, incontinence, idleness, or uncleanliness. "If, for example, a man, through intemperance or extravagance, becomes unable to pay his debts, or, having undertaken the moral responsibility of a family, becomes . . . incapable of supporting or educating them, he is deservedly reprobated . . . but it is for the breach of duty to his family or creditors, not for the [intemperance or] extravagance. . . No person ought to be punished simply for being drunk; but a soldier or a policeman should be punished for being drunk on duty." 31 In essence, when obnoxious conduct does not immediately violate the rights of others it should be endured for the sake of the greater good of human freedom.

III

Mill, like Marcuse, harbored little hope that the public could easily be convinced that it ought to tolerate dissent. "Wherever there is an ascendant class," says Mill, "a large portion of the morality of the country emanates from its class interests . . . ."32 Spontaneity is hardly recognized as having any intrinsic worth, or deserving any regard on its own account. The masses, who are satisfied with the status quo, have little patience with individualists who disdain established ways, and even social reformers usually belittle spontaneity, fearing it may threaten their pet reforms. ${ }^{33}$ "[S]ociety," Mill concludes, "has now fairly got the better of individuality . . . ." 34 "At present individuals are lost in the crowd. . . . Their thinking is done for them by men much like themselves, addressing them or speaking in their name . . . through the newspapers." 35 Marcuse updates and intensifies these views.

28 Id. 124.

29 Id. 125.

30 Id. 153.

31 Id. 185-86.

32 Id. 91.

33 Id. 154.

34 Id. 159.

35 Id. 165-66. 
Mill also seems to have anticipated Marcuse's awareness that men have never lived up to their capacity for sensitivity and taste. Mill looks on the measurement of a man's worth as properly made not only by looking at his deeds but also by taking into account the manner of man he is. "Human nature is not a machine to be built after a model, and set to do exactly the work prescribed for it, [it is like a] tree, which requires to grow and develop itself on all sides, according to the tendency of the inward forces which make it a living thing." 36

Unlike Marcuse, Mill did not believe that promoting men's liberty releases a considerateness for others lying repressed in human breasts. Mill had little foreknowledge of modern psychiatry; not surprisingly, he did not consider the effect of suppressions on man's libido. He was a bit of a snob. "[T] here are but few persons, in comparison with the whole of mankind, whose experiments, if adopted by others, would be likely to be any improvement on established practice. But these few are the salt of the earth; without them, human life would become a stagnant pool." 37 There is no counterpart of this "salt of the earth" theory in Marcuse's writing; he does not believe that sensitivity will spread as a result of following a few fine examples. Instead, Marcuse says, the people of the world, once liberated, will each naturally become tender and full-souled on his own. When the new sensuous culture follows on liberation, people intuitively will recognize and shun stupidity, falsity, and evil. Production plans will become so well attuned to the life instincts that men's libidos will supply the impetus for doing the world's work. The liberation of genuine human nature will set in motion man's natural desire to create a society that will be the greatest work of art of the coming aesthetic ethos.

Some other students of psychiatry are less confident than Marcuse about man's innate tenderness. Dr. Robert Waelder (who himself sat at the feet of Freud) wrote in 1966, "All morality is a restriction and modification of inborn strivings. If man were . . . good by nature, no morality would be needed . . . . In our days . . . men are expected [by reformers] to be concerned only about the good of all and not about their own personal interests. Aggression in the service of . . . selfaggrandizement including . . . one man considering himself as better than another . . . is completely condemned." 38 Dr. Waelder also points to scientific research on group behavior of both chickens and baboons which reveals that these animals live socially stratified lives and often act brutally to each other. "The moralists of today," Dr. Waelder continues, "try to purge man of all selfishness and personal

36 Id. 157.

37 Id. 163.

38 Waelder, The Concept of Justice and the Quest for a Perfectly Just Society, 115 U. PA. L. Rev. 1, 8-9 (1966). 
aggressiveness; they refuse to believe that, in most cases, self-concern and a measure of aggressiveness cannot be completely suppressed except at enormous cost in terms of other human values. . . . [A]n egalitarian society needs an authority which has the power to enforce equality and which sees to it that nobody gets out of line." 39 Marcuse's prophecy that men will become nonaggressive and tender when liberated from corporate capitalism seems at odds with Waelder's theory.

Mill would probably have been standoffish about both Marcuse's and Waelder's opinions on the wellsprings of men's conduct. Mill put his trust in man's ability to improve his lot by deliberation; through constant resort to his rational faculties, man could and would, bit by bit, improve society. "[T] he source of everything respectable in man either as an intellectual or as a moral being [is] that his errors are corrigible. He is capable of rectifying his mistakes, by discussion and experience." 40

We surely should accept Mill's opinion that various forms of deliberation on untoward experience may lead to the correction of mistakes of fact. Rethinking has improved sciences (like physics) and crafts (like carpentry). The whole truth about the good life, however, exists as fact for Mill; once that truth is discerned (accurately and fully) and explained (clearly and widely), all men with good sense will understand it and live by it.

To discover to the world something which deeply concerns it . . . to prove to it that it had been mistaken on some vital point of temporal or spiritual interest, is as important a service as a human being can render to his fellow creatures . . . History teems with instances of truth put down by persecution. If not suppressed for ever, it may be thrown back for centuries. . . The real advantage which truth has consists in this, that when an opinion is true, it may be extinguished once, twice, or many times, but in the course of the ages there will generally be found persons to rediscover it, until some one of its reappearances falls on a time when from favourable circumstances it escapes persecution until it has made such head as to withstand all subsequent attempts to suppress it. ${ }^{41}$

$39 \mathrm{Id}$. 10-11. I reacted in print against Waelder's views because he seems, once his whole article is read, to voice complacency with inequities that may be meliorated. My reply points out that slavery, child labor, droit du seigneur, imprisonment for debt, and other aggressive outrages had been, in some societies, recognized as evils and downed, by and large, by outlawry and without loss of other important values. Morris, $A$ Dissent to Dr. Waelder's. Theory of Justice, 115 U. PA. L. REv. 12, 13 (1966). My dissent ended in a rhetorical question to this effect: Shall we believe that because some men are so made that we cannot quench their aggressive desire for high status, others must inevitably be second class members of the human race? $I d .16$.

40 Mrr, supra note 19, at 108.

41 Id. 117-19. 
The instances of suppression of truth that Mill had in mind were such outrages as the Spanish Inquisition's short-lived, sixteenth century suppression of Copernican astronomy. ${ }^{42}$ Science's discoveries were not, however, seriously threatened with censorship in Mill's own day. His Victorian world was, of course, afflicted with prudery and posturing, against which he inveighed. The blights that cried out for reform when he was writing On Liberty were, however, dire poverty, paucity of education, child labor, industrial accidents, and poor sanitation. True, knowledge of the facts bearing on these evils was then sparse, but lack of public concern resulted as much from inertia as from suppression. In mid-nineteenth century, Mill and his fellow liberals were interested in a few worthy causes, such as women's suffrage, but by and large they did little to understand (much less develop) the aspirations of the general public. They did not deplore that many people were hardly citizens; that is, many people hardly counted. Too few of the elite concerned themselves with social betterment, and those who did, including Mill, wanted to give the masses what was deemed good for them rather than to clarify and implement the widely shared values of their society.

Most of the elders of modern western societies have tended to regard proposals for wide social change with suspicion and apprehension. Nevertheless, the human condition has been, in various ways, irreversibly meliorated in the past dozen decades. The legitimated procedures of social change have produced some advances which accord with the unformulated, but known, general will. Perhaps our legitimated procedures can be used effectively in the future to down great lurking evils (like overpopulation and pollution) which are now at odds with the public's aspirations. Society's permitted, lawful methods of change have, however, often been found wanting. Determined and selfish autocracies in France and Russia were unseated only after bloody revolutions, and the United States was unable to outlaw slavery without a civil war.

Marcuse believes that we need revolution now; that social perversions introjected into our biology by corporate capitalism cannot be cleared away by using legitimate methods of law reform; that parliamentary change moves at a futile, snail's pace. He may be right.

Mill's defense of liberty is calculated to advance justice insofar as (and only insofar as) dissidents' protests and examples awake or change and invigorate the public's aspirations. Modern day protests and confrontations have stimulated some re-examinations of our law

42 Certainly the English theologic objections to the theory of evolution voiced in Mill's own day did not silence Darwin or his followers, and would fall within Mill's own protection of free speech. 
and mores. At times they also have evoked deeply felt divisivenessa condition which, by definition, disrupts the wide sharing of values and, at least for the nonce, prevents the solidification of new and better public aspirations. Unless and until values are widely shared, there is no base on which to rest justice. ${ }^{43}$ Perhaps, however, time, births, and deaths will turn some of our ferments into new solid values, shared widely enough to be the whole public's, rather than a lesser group's, aspirations. This does not, of course, mean that all dissidents have their fingers on, or even near to, the pulse of the future.

The one injustice that can persist (even when the public does not aspire to its correction) is exclusion of groups of adults from participation in the processes of formulating the public's aspirations. Mill's call for free speech and uninhibited verve falls short of full enfranchisement of the dispossessed; he does not press on to advocate education of the uneducated and advantaging the disadvantaged; he does not urge that they be given the liberty to become fully active citizens. Free speech is a snide gift to present to the unarticulate; the right to hear is rarely serviceable to the benighted. Tolerance toward eccentricity is of little value to those who must so live and work that they have little energy or opportunity for nonchemically induced verve. In sum, Mill's liberties, valuable though they are, were not adequate to dislodge the suppressions of his time, much less ours.

Marcuse, on the other hand, is concerned with liberation which will unyoke each man's pent-up ability to understand his natural desires and to harmonize each individual's hopes with mankind's genuine social goals. After liberation the entire public, according to Marcuse, will enjoy all the individual freedoms that any one can, in justice, claim; liberated society will afford everyone liberty consistent with social perfection. The solidarity that will result from Marcuse's new individual liberty is instinctual; it will flow from the hearts of men released from the unnatural repressions of corporate capitalism.

Marcuse puts no trust in the rational faculties of either the prerevolutionary public or those public servants who officiate steadfastly. He writes off the possibility that our society as a whole already has, to some extent, genuine aspirations for individual freedom which have been at least partly understood and attained. This rejection of Mill's case for rationality seems unwarranted. Rational discourse can, in some sectors, advance civilization; public discussion looking toward ways for overcoming shortcomings are of value. Cool development of facts is often enough. Public disclosure of the effects on dental health and

43 See Morris, Lazw, Justice, and the Public's Aspirations, in Nomos VI, Jusrrce 170 (C. Friedrich \& J. Chapman eds. 1963). 
the dollar costs of water fluoridation were, for example, persuasive enough for social action. Other social problems refuse to remain so factual, and are met only when our hearts as well as our heads are moved. The economic, social, and educational problems of liberating the ghetto blacks are, for example, problems of will as well as of way. Marcuse's essay celebrates the potential of all of humanity. $\mathrm{He}$ is right in looking with disfavor on some of the tastes and many of the goals of contemporary society; some social reorientations could release more of our better natures. Clarified intuition of the unchallengeable worth of humans and the right of every man to count is of first importance. Adequate respect for the humanity of man will be only theoretical, however, unless and until society consists of an all inclusive public capable of maturing widely shared values and served by men capable of discovering and implementing the public's aspirations. Revolution, at most, can redirect the slow processes of amelioration. Perhaps Mill's case for a continuously developing right of discourse, plus Marcuse's inspiration for enlivened intuition of man's worth, will inspire needed protests and confrontations that will dissolve unwarranted complacency. Liberation from complacency, however, does not win through when everyone fights to be the first to hear and accede to new prophets' proclamations. Liberty to remember what we have learned, to consider where we should go, to refine the best of proposals, and to dissent from unworthy programs may slow down social changes; these liberties, nevertheless, may contribute much to advancing and protecting the common good. New whims may happen to be better than old conceits. The novelty and excitement of new whims, however, do not guarantee that they are nascent, genuine public aspirations. 